\title{
Influence of tannery wastes and the surrounding environment of tannery industries on microbial growth and proliferation
}

\author{
Nayan Chandra Das, Farzana Hossaini and Saurab kishore Munshi* \\ Department of Microbiology, Stamford University Bangladesh, 51 Siddeswari Road, Dhaka 1217, Bangladesh
}

Received 17 April 2017/Accepted 28 May 2017

\begin{abstract}
The present study was carried out to assess the degree of microbiological proliferation in tannery wastes and the surrounding environment of the tannery industries. In this regard, a total of 8 tannery waste $(n=4)$ and environmental $(n=4)$ samples were tested. All the samples contained a huge load of bacteria and fungi in an average of $10^{8} \mathrm{cfu} / \mathrm{g}$ or $\mathrm{ml}$. An extended numbers of pathogenic bacteria were recovered. Among the pathogenic bacteria, Staphylococcus spp. was predominant. Most of the samples exhibited the presence of Pseudomonas spp. Salmonella spp. and fecal coliform were found each in one sample. Bacillus spp., Escherichia coli, Klebsiella spp. and Vibrio spp. were found in few samples. The average load of the pathogens was $10^{4} \mathrm{cfu} / \mathrm{g}$ or $\mathrm{ml}$. All the pathogenic isolates were found to be multidrug resistant. Higher resistance was found against penicillin and streptomycin. Tannery waste after lather treatment sample showed antibacterial activity against all the pathogens tested. Overall, presence of pathogenic microorganisms with multidrug resistance traits may pose serious public health threats.
\end{abstract}

Key words: Tannery wastes; Microbiological proliferation; Drug resistance; Antibacterial activity

Industrial wastes are usually originated from various industrial processes, and the amount and toxicity of waste released from industrial activities varies with the industrial processes. Noticeably, among all the industrial wastes tannery effluents are ranked as the highest pollutants (1-3). Industrial pollution remains one of the major problems of Bangladesh, especially in the urban areas where effluent discharge practices are yet too primitive $(4,5)$. Industrial units including tannery are mostly located along the banks of the rivers vastly due to the ease of transportation for incoming raw materials and outgoing finished products (5). These industrial units can act in generating a considerable amount of pollution by discharging untreated effluents directly into the environment $(4,5)$.

Tanning industry generates large quantities of solid wastes during the leather manufacturing process and subsequently during effluent treatment. During this process, different wastes such as meat separated from skin, fat tissue, hair, sludge, and chromium are generated (6). Tannery effluent is among one of the most hazardous industrial pollutants. Major problems are due to wastewater containing heavy metals, toxic chemicals, chloride and lime with high dissolved and suspended salts and other pollutants which may severely affect the growth of living organisms including microorganisms (7-9). The contamination of metals is a

*Corresponding Author: Mailing address. Saurab Kishore Munshi, Assistant Professor, Department of Microbiology, Stamford University Bangladesh, 51 Siddeswari Road, Dhaka 1217, Bangladesh, Bangladesh; E-mail: kishore016@yahoo.com; skmunshi@stamforduniversity.edu.bd. major environmental problem, especially for aquatic environment (10-14). Metals that remain in contaminated sediments in the surrounding environment of tannery industry may accumulate in microorganisms that can enter into the food chain and eventually affect human well-being (15).

In addition, the organic pollutants present in tannery wastewater are not completely degraded even after the secondary treatment process and support the growth of pathogenic microbes including coliform, Streptococci, Staphylococci, anaerobic spore forming bacilli, and many other types of health hazards organisms. These pathogens can easily spread into the aquatic environment as well as the surrounding environment along with tannery wastewater and cause serious health hazards to living organisms (16). Despite large advances in water and wastewater treatment processes, waterborne diseases still pose a major worldwide threat to public health. There are several reports available regarding the presence of a variety of organic pollutants and pathogenic microbes including the drug resistant ones in various types of industrial wastewaters (16-19).

Considering all these facts, present study endeavored to estimate the possible proliferation of pathogenic microorganisms in the wastes disposed by the tannery industries and the surrounding environment of the industrial units. The present study was also carried out to determine the antibiotic resistance of the bacterial isolates. Moreover, antibacterial traits of the wastes and environmental samples were determined. 


\section{MATERIALS AND METHODS}

Study area, sampling and sample processing. Four different types of tannery waste samples (tannery wastes after lather treatment, $\mathrm{CaCO}_{3}$ containing wastes, liquid tannery wastes and solid tannery wastes) and four different environmental samples (surface water from lake, dry soil sample from waste dumping area, solid wastes from dumping area and wet soil sample from waste dumping area) were randomly collected from a tannery industry located at Hazaribagh, Dhaka, Bangladesh and its surrounding environment from November 2015 to January 2016 following standard protocol. For the identification and enumeration of pathogenic bacteria and fungi, $10 \mathrm{~g}$ or $\mathrm{ml}$ of each sample was blended with $90 \mathrm{ml}$ of buffer peptone water $(\mathrm{pH} 7.2 \pm 0.2)$ and diluted up to $10^{-6}$ for all the samples tested according to the standard guideline (20-24).

Isolation and identification of bacteria

Estimation of total viable bacteria, Escherichia coli, Klebsiella spp., Staphylococcus spp. Bacillus spp. and Pseudomonas spp. For each of the cases, $0.1 \mathrm{ml}$ of samples from the dilution $\left(10^{-4}\right.$ and $\left.10^{-6}\right)$ for the solid and $\left(10^{-2}\right.$ and $10^{-4}$ ) for the liquid was introduced on to the nutrient agar and sabouraud dextrose agar for the isolation of total viable bacteria and fungi, respectively. Likewise, each sample was introduced onto MacConkey agar, mannitol salt agar (MSA), starch agar and Pseudomonas agar for the isolation of coliforms (Escherichia coli and Klebsiella spp.), Staphylococcus spp., Bacillus spp. and Pseudomonas spp., consecutively. All the plates were then incubated at $37{ }^{\circ} \mathrm{C}$ for 24 hours (20-24)

Isolation of Salmonella spp., Shigella spp. and Vibrio spp. By considering the possible occurrence of viable but non-culturable (VBNC) cells (24-28), 10 $\mathrm{ml}$ of sample was transferred into $90 \mathrm{ml}$ of selenite cysteine broth (SCB) and alkaline peptone water (APW) for the enrichment of Salmonella spp., Shigella spp., and Vibrio spp., respectively and incubated at $37{ }^{\circ} \mathrm{C}$ for 6 hours. After incubation, the samples were diluted up to $10^{-4}$ and then $0.1 \mathrm{ml}$ of samples from each of the $10^{-2}$ and $10^{-4}$ dilutions were spread onto Salmonella-Shigella (SS) agar and thiosulfate citrate bile salt sucrose (TCBS) agar for the isolation of Salmonella spp. \& Shigella spp., and Vibrio spp., consecutively. Plates were incubated at $37^{\circ} \mathrm{C}$ for 48 hours for the detection of typical colonies.

Antibiotic susceptibility test of the isolates. The standard agar-disc-diffusion method (Kirby Bauer technique) was used to examine the antibiotic susceptibility of the isolates (either sensitive or resistance) on Mueller-Hinton agar (Difco, Detroit, MI) $(24,29-31)$. The antibiotic discs used in this experiment were Ampicillin (AMP, $10 \mu \mathrm{g}$ ), Imipenem (IPM, $10 \mu \mathrm{g}$ ), Azithromycin (AZI, 15 $\mu \mathrm{g}$ ), Penicillin (PEN, 10 $\mu \mathrm{g})$, Gentamycin (GEN, $10 \mu \mathrm{g}$ ), Streptomycin (STM, 10 $\mu \mathrm{g}$ ),

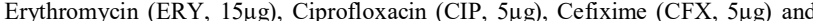
Chloramphenicol (CHL, $10 \mu \mathrm{g})$. The plates were then inverted and incubated at 37 ${ }^{\circ} \mathrm{C}$ for 24 hours. After incubation, the plates were examined and the zone of inhibition was measured in $\mathrm{mm}$.

Antimicrobial assay. For the determination of antimicrobial activity, modified agar well diffusion method was followed using Mueller-Hinton agar plate $(24,32$, 33). Suspensions of different bacteria such as E. coli, Pseudomonas spp., Micrococcus spp., Vibrio spp., Klebsiella spp., Staphylococcus aureus, and Salmonella spp. was introduced on to the MHA agar were prepared using normal saline, consisting of $10^{6} \mathrm{cfu} / \mathrm{ml}$ with a turbidity equivalent to that of the $0.5 \mathrm{~mL}$ McFarland standard, and each suspension was then subject to lawn on the MullerHinton agar (MHA) (Oxoid Ltd., Basingstoke, Hampshire, England). The wells were dug $\left(8 \mathrm{~mm}^{3}\right)$ on the inoculated Muller Hinton agar medium and $100 \mu \mathrm{l}$ or $11 \mathrm{mg} / \mathrm{ml}$ of each sample were introduced. Normal saline was used as negative controls whereas antibiotic disk of Gentamycin (GEN, $10 \mu \mathrm{g}$ ) was used as positive control. The plates were incubated at $37^{\circ} \mathrm{C}$ overnight and examined for the zone of inhibition. The diameter of the inhibition zone was measured in $\mathrm{mm}$ using slide calipers

\section{RESULTS AND DISCUSSION}

Determination of the presence of pathogenic bacteria from the tannery wastes and environmental samples tested. Proliferation of drug resistant bacteria in the aquatic environment has been drastically accelerated due to the unregulated disposal of industrial, hospital and domestic wastes containing organic substances along with toxic chemicals $(18,34-39)$. In this study, all the samples were found to contain huge load of viable bacteria in

TABLE 1. Isolation and quantification of pathogenic bacteria from tannery waste and environmental samples

\begin{tabular}{|c|c|c|c|c|c|c|c|c|c|c|}
\hline \multirow[b]{2}{*}{ Sample } & \multicolumn{10}{|c|}{ Microbial load (cfu/ml or $\mathrm{g})$} \\
\hline & TVB & Fungi & E. coli & $\begin{array}{c}\text { Klebsiella } \\
\text { spp. }\end{array}$ & $\begin{array}{c}\text { Fecal } \\
\text { coliform }\end{array}$ & $\begin{array}{l}\text { *Salmonella } \\
\text { spp. }\end{array}$ & $\begin{array}{l}\text { Pseudomonas } \\
\text { spp. }\end{array}$ & $\begin{array}{c}\text { Bacillus } \\
\text { spp }\end{array}$ & $\begin{array}{l}\text { *Vibrio } \\
\text { spp. }\end{array}$ & $\begin{array}{c}\text { Staphylococcus } \\
\text { spp. }\end{array}$ \\
\hline $\begin{array}{c}\text { tannery } \\
\text { wastes after } \\
\text { lather } \\
\text { treatment }\end{array}$ & $5.0 \times 10^{8}$ & $3.2 \times 10^{8}$ & 0 & 0 & 0 & 0 & $1.8 \times 10^{6}$ & 0 & 0 & $2.0 \times 10^{6}$ \\
\hline $\begin{array}{c}\mathrm{CaCO}_{3} \\
\text { containing } \\
\text { wastes }\end{array}$ & $3.2 \times 10^{8}$ & $1.4 \times 10^{8}$ & $2.5 \times 10^{5}$ & 0 & $4.2 \times 10^{4}$ & 0 & $2.5 \times 10^{7}$ & $2.9 \times 10^{5}$ & $7.2 \times 10^{5}$ & $1.6 \times 10^{7}$ \\
\hline $\begin{array}{l}\text { liquid tannery } \\
\text { wastes }\end{array}$ & $1.5 \times 10^{8}$ & $4.8 \times 10^{8}$ & $2.8 \times 10^{3}$ & $2.9 \times 10^{4}$ & 0 & 0 & 0 & $1.8 \times 10^{5}$ & $4.9 \times 10^{4}$ & $2.6 \times 10^{5}$ \\
\hline $\begin{array}{l}\text { solid tannery } \\
\text { wastes }\end{array}$ & $3.4 \times 10^{8}$ & $1.7 \times 10^{8}$ & 0 & $1.2 \times 10^{4}$ & 0 & $3.8 \times 10^{4}$ & $3.9 \times 10^{6}$ & $2.2 \times 10^{4}$ & $1.9 \times 10^{5}$ & $3.1 \times 10^{6}$ \\
\hline $\begin{array}{l}\text { surface water } \\
\text { from lake }\end{array}$ & $2.8 \times 10^{8}$ & $5.7 \times 10^{5}$ & 0 & 0 & 0 & 0 & $1.0 \times 10^{6}$ & 0 & 0 & $3.7 \times 10^{5}$ \\
\hline $\begin{array}{c}\text { dry soil } \\
\text { sample from } \\
\text { waste } \\
\text { dumping area }\end{array}$ & $5.8 \times 10^{8}$ & $3.8 \times 10^{8}$ & $2.2 \times 10^{4}$ & 0 & 0 & 0 & $2.2 \times 10^{6}$ & $2.0 \times 10^{5}$ & 0 & $1.8 \times 10^{5}$ \\
\hline $\begin{array}{l}\text { solid wastes } \\
\text { from } \\
\text { dumping area }\end{array}$ & $4.3 \times 10^{8}$ & 0 & 0 & 0 & 0 & 0 & $3.2 \times 10^{5}$ & 0 & 0 & $5.3 \times 10^{5}$ \\
\hline $\begin{array}{l}\text { Wet wastes } \\
\text { from } \\
\text { dumping area }\end{array}$ & $3.2 \times 10^{8}$ & 0 & 0 & 0 & 0 & 0 & $2.6 \times 10^{6}$ & 0 & 0 & $4.3 \times 10^{5}$ \\
\hline
\end{tabular}

TVB = Total viable bacteria

The experiments were in triplicates. Average count $(\mathrm{cfu} / \mathrm{ml}$ or $\mathrm{g})$ from all samples have been shown here.

*Bacterial load after enrichment (Prior to enrichment, the recovery was nil).

Shigella spp. was absent in all samples. 
TABLE 2. Antimicrobial susceptibility pattern of different pathogenic isolates

\begin{tabular}{|c|c|c|c|c|c|c|c|c|c|c|c|c|}
\hline \multirow{2}{*}{ Antibiotics } & \multicolumn{2}{|c|}{$\begin{array}{c}\text { E. coli } \\
\mathbf{n}=3\end{array}$} & \multicolumn{2}{|c|}{$\begin{array}{c}\text { Klebsiella } \\
\mathbf{n}=2\end{array}$} & \multicolumn{2}{|c|}{ 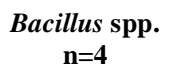 } & \multicolumn{2}{|c|}{$\begin{array}{l}\text { Vibrio spp. } \\
\quad \mathbf{n}=\mathbf{3}\end{array}$} & \multicolumn{2}{|c|}{$\begin{array}{c}\begin{array}{c}\text { Staphylococcus spp. } \\
\mathbf{n}=8\end{array} \\
\text {. }\end{array}$} & \multicolumn{2}{|c|}{$\begin{array}{c}\text { Pseudomonas spp. } \\
\mathrm{n}=7\end{array}$} \\
\hline & $\mathbf{R}$ & $\mathbf{S}$ & $\mathbf{R}$ & $\mathbf{S}$ & $\mathbf{R}$ & $\mathbf{S}$ & $\mathbf{R}$ & $\mathbf{S}$ & $\mathbf{R}$ & $\mathbf{S}$ & $\bar{R}$ & $\mathbf{S}$ \\
\hline AMP $(10 \mu \mathrm{g})$ & $100 \%$ & $0 \%$ & $100 \%$ & $0 \%$ & $50 \%$ & $50 \%$ & $100 \%$ & $0 \%$ & $0 \%$ & $100 \%$ & $87.5 \%$ & $0 \%$ \\
\hline $\mathrm{CIP}(5 \mu \mathrm{g})$ & $33 \%$ & $67 \%$ & $50 \%$ & $33 \%$ & $25 \%$ & $100 \%$ & $0 \%$ & $100 \%$ & $50 \%$ & $50 \%$ & $0 \%$ & $100 \%$ \\
\hline STM $(10 \mu \mathrm{g})$ & $100 \%$ & $0 \%$ & $100 \%$ & $0 \%$ & $50 \%$ & $67 \%$ & $33 \%$ & $50 \%$ & $100 \%$ & $0 \%$ & $100 \%$ & $0 \%$ \\
\hline IPM $(30 \mu \mathrm{g})$ & $0 \%$ & $100 \%$ & $50 \%$ & $50 \%$ & $0 \mid \%$ & $100 \%$ & $0 \%$ & $100 \%$ & $0 \%$ & $100 \%$ & $0 \%$ & $100 \%$ \\
\hline PEN $(10 \mu \mathrm{g})$ & $100 \%$ & $0 \%$ & $100 \%$ & $0 \%$ & ND & ND & $100 \%$ & $0 \%$ & $0 \%$ & $100 \%$ & $57 \%$ & $43 \%$ \\
\hline $\operatorname{GEN}(10 \mu \mathrm{g})$ & $0 \%$ & $100 \%$ & $0 \%$ & $100 \%$ & $0 \%$ & $100 \%$ & $0 \%$ & $100 \%$ & $0 \%$ & $100 \%$ & $29 \%$ & $71 \%$ \\
\hline AZI $(15 \mu \mathrm{g})$ & $0 \%$ & $100 \%$ & $50 \%$ & $50 \%$ & $50 \%$ & $50 \%$ & $0 \%$ & $100 \%$ & $0 \%$ & $100 \%$ & $29 \%$ & $71 \%$ \\
\hline $\mathrm{CFX}(5 \mu \mathrm{g})$ & $100 \%$ & $0 \%$ & $100 \%$ & $0 \%$ & $0 \%$ & $100 \%$ & $0 \%$ & $100 \%$ & $0 \%$ & $100 \%$ & $43 \%$ & $57 \%$ \\
\hline ERY $(15 \mu \mathrm{g})$ & $100 \%$ & $0 \%$ & $100 \%$ & $0 \%$ & $50 \%$ & $50 \%$ & $100 \%$ & $0 \%$ & $0 \%$ & $100 \%$ & $29 \%$ & $71 \%$ \\
\hline CHL $(10 \mu \mathrm{g})$ & $33 \%$ & $67 \%$ & $50 \%$ & $50 \%$ & $0 \%$ & $100 \%$ & $0 \%$ & $100 \%$ & $0 \%$ & $100 \%$ & $43 \%$ & $57 \%$ \\
\hline
\end{tabular}

$\mathrm{AMP}=$ Ampicillin, $\mathrm{CIP}=$ Ciprofloxacin, STM= Streptomycin; IPM= Imipenem, ERY= Erythromycin, AZI= Azithromycin, GEN= Gentamycin, $\mathrm{PEN}=$ Penicillin, $\mathrm{CFX}=$ Cerfixime, $\mathrm{STE}=$ Streptomycin. $\mathrm{CHL}=\mathrm{Chloramphenicol}$

$\mathrm{ND}=$ Not done; $\mathrm{N}=$ Number of isolates; $\mathrm{R}=$ Resistant $\mathrm{S}=$ Sensitive

average of $10^{8} \mathrm{cfu} / \mathrm{ml}$ or $\mathrm{g}$ (Table 1) as found previously from tannery waste and different environmental samples $(5,16-20,22,24,29,40)$. A huge array of pathogenic microorganisms was found in tannery wastes of Bangladesh by Siddiqee et al. (41). Fungi were present in all samples in a range of $5.7 \times 10^{5}$ - $3.8 \times 10^{8} \mathrm{cfu} / \mathrm{ml}$ or $\mathrm{g}$ except solid and wet wastes of dumping area. Pathogenic bacteria were also recovered in significant quantities from all the samples, mostly in the $\mathrm{CaCO}_{3}$ containing wastes and solid tannery wastes. Pathogenic proliferation was confirmed through the biochemical tests. Staphylococcus spp. were found to be present in all samples in a range $1.8 \times 10^{5}-1.6 \times 10^{7}$ cfu/g or $\mathrm{ml}$ (Table 1). Pseudomonas spp. was the second prevalent bacteria as found in all samples except liquid tannery wastes. $E$. coli was absent in pharmaceutical and hospital waste water samples but resided in the other four samples within the range of $2.5 \times 10^{3}-3.3 \times 10^{4} \mathrm{cfu} / \mathrm{ml}$ or g. E. coli and Vibrio spp. were found in three samples, whereas Klebsiella spp. and Bacillus spp. were recovered in 2 and 4 samples, respectively in an average of $10^{4} \mathrm{cfu} / \mathrm{g}$ or $\mathrm{ml}$. Salmonella spp. was detected only in solid tannery waste sample, while fecal coliform was present in $\mathrm{CaCO}_{3}$ containing waste sample (Table 1). All the tested samples were free from Shigella spp. Contamination.

Elevated antibiotic resistance of the isolates. In cohort to the previous studies on surface water and wastes, present study recovered a significant number of multidrug resistant isolates $(18,22,29,40)$. Ali et al., (5) also found an extended frequency of drug resistant isolates in the tannery waste. The pathogen showed

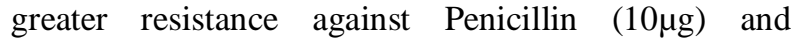
Streptomycin $(10 \mu \mathrm{g})$, whereas sensitivity against Gentamycin $(10 \mu \mathrm{g})$ and Imepenem $(30 \mu \mathrm{g}$, Table 2$)$.
While all the isolates showed resistance against Ampicillin $(10 \mu \mathrm{g})$, Streptococcus spp. showed sensitivity against the antibiotic. Although all Vibrio spp. and Pseudomonas spp. exhibited sensitivity against Ciprofloxacin $(5 \mu \mathrm{g})$, all the other bacteria showed resistance to some extent. Staphylococcus spp. was recovered as sensitive against most of the antibiotic tested.

Antibacterial activity of tannery waste and environmental samples. The tannery wastes are supposed to have antibacterial activity as powders of different heavy metals are used in leather processing at retanning stage to prepare bacterial growth resisting leather (42). Previous study by Nawaz et al. (42) evident the presence of antibacterial activity in tannery waste samples. In the current study, tannery waste after lather treatment sample showed antimicrobial activity against almost all organisms (Table 3). Among all the isolates, larger zone of inhibition was found against Vibrio spp. All the other samples exhibited almost no antibacterial activity. $\mathrm{CaCO}_{3}$ containing waste sample imparted antibacterial activity only against Salmonella spp., whereas, dry soil sample from waste dumping area exhibited antibacterial traits against Klebsiella spp.

\section{CONCLUSION}

The findings of the present study revealed that all the samples contain huge array of microorganisms including pathogenic bacteria. All the isolates were found to be multidrug resistant. Only the solid waste after lather treatment sample exhibited antimicrobial activity. Presence of pathogenic bacteria with antibiotic resistance traits portrayed serious public health threats. As tannery waste and the surrounding ecosystem are known to contain metal pollution which are toxic to human beings, 
TABLE 3. Antimicrobial activity of the samples tested

\begin{tabular}{|c|c|c|c|c|c|c|c|}
\hline \multirow{2}{*}{$\begin{array}{l}\text { Herbal medicine } \\
\text { samples }\end{array}$} & \multicolumn{7}{|c|}{ Zone of inhibition $(\mathrm{mm})$ against test bacteria } \\
\hline & E. coli & $\begin{array}{l}\text { Klebsiella } \\
\text { spp. }\end{array}$ & $\begin{array}{l}\text { Salmonella } \\
\text { spp. }\end{array}$ & $\begin{array}{l}\text { Vibrio } \\
\text { spp. }\end{array}$ & $\begin{array}{l}\text { Pseudomonas } \\
\text { spp. }\end{array}$ & $\begin{array}{l}\text { Micrococcus } \\
\text { spp. }\end{array}$ & $\begin{array}{c}\text { Staphylococcus } \\
\text { spp. }\end{array}$ \\
\hline $\begin{array}{l}\text { tannery wastes after } \\
\text { lather treatment }\end{array}$ & $11 \mathrm{~mm}$ & $12 \mathrm{~mm}$ & $12 \mathrm{~mm}$ & $17 \mathrm{~mm}$ & $11 \mathrm{~mm}$ & $15 \mathrm{~mm}$ & $11 \mathrm{~mm}$ \\
\hline $\begin{array}{c}\mathrm{CaCO}_{3} \text { containing } \\
\text { wastes }\end{array}$ & 0 & 0 & $11 \mathrm{~mm}$ & 0 & 0 & 0 & 0 \\
\hline liquid tannery wastes & 0 & 0 & 0 & 0 & 0 & 0 & 0 \\
\hline solid tannery wastes & 0 & 0 & 0 & 0 & 0 & 0 & 0 \\
\hline surface water from lake & 0 & 0 & 0 & 0 & 0 & 0 & 0 \\
\hline $\begin{array}{l}\text { dry soil sample from } \\
\text { waste dumping area }\end{array}$ & 0 & $16 \mathrm{~mm}$ & 0 & 0 & 0 & 0 & 0 \\
\hline $\begin{array}{l}\text { Dry wastes from } \\
\text { dumping area }\end{array}$ & 0 & 0 & 0 & 0 & 0 & 0 & 0 \\
\hline $\begin{array}{l}\text { Wet wastes from } \\
\text { dumping area }\end{array}$ & 0 & 0 & 0 & 0 & 0 & 0 & 0 \\
\hline
\end{tabular}

adherence of metals on microbial cell surface would enhance the health risk by many folds. Finally, it could be said that adequate preventive and regulatory measures should be taken in tannery industrial activities with a view to ensuring safe, sound and healthy environment for the greater benefit of Bangladesh.

\section{ACKNOWLEDGEMENT}

We thank Microbiology Laboratory, Stamford University Bangladesh for laboratory facilities, technical assistance and financial aid.

\section{REFERENCES}

1. Ijeoma K, Achi OK. 2011. Industrial effluents and their impact on water quality of receiving rivers in Nigeria. J. Appl. Technol. Environ. San. 1 (1): $75-86$.

2. Fakayode SO. 2005. Impact of industrial effluent on water quality of the receiving Alaro river in Ibadan Nigeria, Ajeam-Ragee. 10: 1-13.

3. Glyn H.J., and W.H. Gary, 1996. Environmental sciences and engineering. Prentice Hall International Inc.

4. Khan SR, Kawja MA, Khan AM, Ghani H, Kazmi S. 1999. Environmental impacts and mitigation costs associated with cloth leather exports from Pakistan. Available at:

http://www.tradeknowledgenetwork.net/pdf/sdpifullrprt_s.pdf. Accessed August 23, 2016

5. Ali MA, Chowdhury FM, Islam TH, Datta S. 2015. Multidrug resistance pattern of bacteria isolated from domestic and tannery waste. IOSR J. Pharm. Biol. Sci. 10 (1): 12-17.

6. Post V. 1997. Waste disposal management with special emphasis on current issues in tannery effluent treatment plant sludge disposal. Proc 30th Leath Res Ind Get Together (CLRI, Chennai).

7. Emonger V, Nkegbe E, Kealotswe B, Koorapetse I, Sankwase S, Keikanetswe S. 2005. Pollution indicators in Gaborone industrial effluent, J. Appl. Sci. 5: 147-150.

8. Phiri O, Mumba P, Moyo BHZ, Kadewa W. 2005. Assessment of the impact of industrial effluents on water quality of receiving rivers in urban areas of Malawi. Intl. J. Environ. Sci. Technol. 2: 237-244.

9. Otokunefor TV, Obiukwu C. 2005 Impact of refinery effluent on the physicochemical properties of a water body in the Niger Delta. Appl. Ecolog. Environ. Res. 3: 61-72.

10. Weirsema VD, Hwshoffpol LW, Dewit J. 1996. Livestock and the environment: finding a balance management of waste from animal product processing, International Agriculture Centre, Wageningen, Netherlands.

11. Uberoi, NK. 2003. Environmental management. Excel Books Publiser, New Delhi.

12. Nandy T, Kaul SN, Shastry S, Manivel W, Deshpande CV. 1999 Wastewater management in cluster of tanneries in Tamil Nadu through implementation of common treatment plants. J. Scien. Ind. Res. 58: 475-516.

13. Ho YC, Show KY, Guo XX, Norli I, Abbas FMA, Morad N. 2012. Industrial discharge and their effect to the environment, In K. Y. Show and X. Guo (Eds.), Industrial Waste. Intech, New York, USA

14. Shakeri A, Moore F. 2010. The impact of an industrial complex on freshly deposited sediments, Chener Rahdar river case study, Shiraz, Iran. Environmental Monitoring and Assessment. 169: 321-334.

15. American Public Health Association. 2005. Standards methods for the examination of water and wastewater. American Public Health Association, Washington, D.C.

16. Yadav A, Mishra S, Kaithwas G, Raj A, Bharagava RN. 2016. Organic pollutants and pathogenic bacteria in tannery wastewater and their removal strategies. Micr. Environl. Man. 5: 101-127.

17. Veni K, Ravindhranath K. 2012. Influence of tannery effluent discharge on the microbiological and physicochemical quality. Chem. Pharm. Res. 4 (1): 656-668.

18. Schwartz T, Kohnen W, Jansen B, Obst U. 2003. Detection of antibioticresistant bacteria and their resistance genes in wastewater, surface water, and drinking water biofilms. FEMS Microbiol. Ecol. 43: 325-335.

19. El-Lathy MA, El-Taweel GE, El-Sonosy WM, Samhan FA, Moussa TAA. (2009). Determination of pathogenic bacteria in wastewater using conventional and PCR techniques. Environ. Biotechnol. 5 (2): 73-80.

20. Chowdhury FFK, Acharjee M, Noor R. 2016. Maintenance of Environmental Sustainability Through Microbiological Study of Pharmaceutical Solid Wastes. CLEAN - Soil, Air,Water. 44: 309-316.

21. Cappuccino JG, Sherman N. 1996. Microbiology - A laboratory manual. The Benjamin/Cummings Publishing Co., Inc., Menlo Park, California.

22. Acharjee M, Jahan F, Rahman F, Noor R. (2013). Bacterial proliferation in municipal water supplied in mirpur locality of Dhaka city, Bangladesh. Clean Soil Air Water. 41: 1-8

23. Acharjee M, Ahmed E, Munshi SK, Noor R. 2014. Validation of $\square-$ irradiation in controlling microorganisms in fish. Nutrn. Food Sci. 44 (3): 258-266.

24. Ahmed T, Urmi NJ, Munna MS, Das KK, Acharjee M, Rahman MM, et al. 2014. Assessment of microbiological proliferation and in vitro demonstration of the antimicrobial activity of the commonly available salad vegetables within Dhaka metropolis, Bangladesh. Am. J. Agri. Forestr. 2 (3): 55-60.

25. Rahman F, Noor R. 2012. Prevalence of pathogenic bacteria in common salad vegetables of Dhaka metropilis. Bang. J. Bot. 41 (2): 159-162.

26. Colwell RR. 2000. Non-culturable microorganisms in the environment. American Society of Microbiology, Washington DC, USA.

27. Oliver JD. 2005. The viable but nonculturable state in bacteria. J. Microbiol. 43: 93-100. 
28. Alfrad EB. 2007. Bensons microbiological applications. Mcgraw-Hill Book Company, New York.

29. Munshi SK, Rahman MM, Noor R. 2012. Detection of virulence potential of diarrheagenic Escherichia coli isolated from surface water rivers surrounding Dhaka city. J. Bang. Acad. Sci. 36 (1): 109-121.

30. Bauer AW, Kirby WMM, Sherris JC, Tierch M. 1968. Antibiotic susceptibility testing by a standardized single disc method. American J. Clin. Pathol. 45 (4): 493-496.

31. Ferraro MJ, Craig WA, Dudley MN. 2001. Performance standards for antimicrobial susceptibility testing. NCCLS, Pennsylvania, USA.

32. Sharmin M, Nur IT, Acharjee M, Munshe SK, Noor R. 2014 Microbiological profiling and the demonstration of in vitro anti-bacterial traits of the major oral herbal medicines used in Dhaka Metropolis. SpringerPlus. 3: 739.

33. Gould GW. 1995. Industry perspective on the use of natura antimicrobials and inhibitors for foods application. J. Food Protectn. 45: 82-86.

34. Choudhury R, Panda S, Singh DV. 2012. Emergence and dissemination of antibiotic resistance: A global problem. Indian J. Med. Microbiol. 30 (4): 384-390.
35. Wang H, Dzink-Fox JL, Chen M, Levy SB 2001. Genetic characterization of highly fluoroquinolone-resistant clinical Escherichia coli strains from China: role of acrR mutations. Antimicrob. Agents Chemother. 45: 15151521.

36. Ochman H, Lawrence JG, Groisman EA. 2000. Lateral gene transfer and the nature of bacterial innovation. Nature. 405: 299-304S.

37. Davies J, Davies D. 2010. Origins and evolution of antibiotic resistance. Microbiol. Mol. Biol. Rev. 74: 417-433.

38. Lee HH, Molla MN, Cantor CR, Collins JJ. 2010. Bacterial charity work leads to population-wide resistance. Nature. 467: 82-86.

39. Woodford N, Ellington MJ. 2007. The emergence of antibiotic resistance by mutation. Clin. Microbiol. Infect. 13: 5-18.

40. Acharjee M, Rahman F, Beauty SA, Feroz F, Rahman MM, Noor R. 2011. Microbiological study on supply water and treated water in Dhaka city. S. J. Microbial. 1 (1): 42-45.

41. Siddiqee MH, Islam MS, Rahman MM. 2012. Assessment of pollution caused by tannery-waste and its impact on aquatic bacterial community in Hajaribag, Dhaka. S. J. Microbial. 2 (1): 20-23.

42. Nawaz HR, Solangi BA, Zehra B, Nadeem U. 2011. Preparation of nano zinc oxide and its application in leather as a retanning and antibacterial agent. Canadian J. Sci. Indus. Res. 2 (4): 164-170. 